\title{
Single coronary artery with high aortic take-off-a rare coronary anomaly
}

\author{
Arvind Kandoria, Kunal Mahajan, Neeraj Ganju, Sachin Sondhi
}

- Additional material is published online only. To view, please visit the journal online (http://dx.doi.org/10.1136/ bcr-2017-223165).

Department of Cardiology, Indira Gandhi Medical College, Shimla, Himachal Pradesh, India

\section{Correspondence to} Dr Kunal Mahajan, kunalmahajan442@gmail.com

Accepted 29 October 2017

\section{CrossMark}

\section{To cite: Kandoria $\mathrm{A}$,} Mahajan K, Ganju N, et al. BMJ Case Rep Published Online First: [please include Day Month Year]. doi:10.1136/bcr-2017-

223165

\section{DESCRIPTION}

High take-off of coronary arteries refers to the origin of coronary arteries $>1 \mathrm{~cm}$ above the

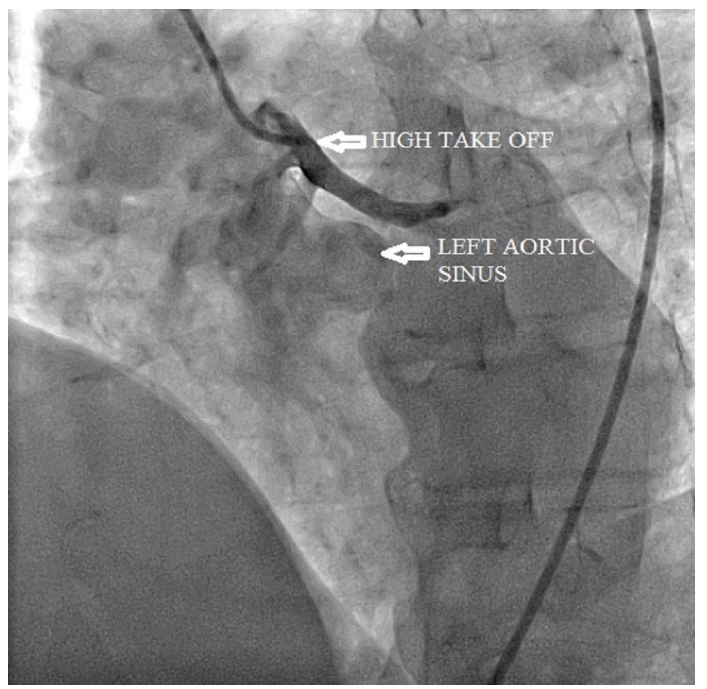

Figure 1 Coronary angiogram, left anterior oblique view, showing an abnormally high take-off of coronary artery from the aorta, $21 \mathrm{~mm}$ above the left coronary sinus.

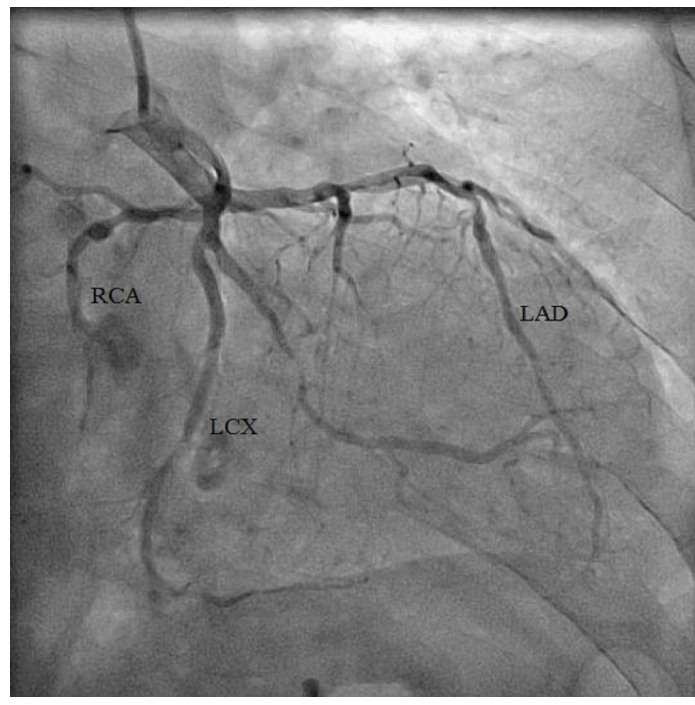

Figure 2 Coronary angiogram, right anterior oblique caudal view, showing a single coronary artery. Note that right coronary artery (RCA) courses medially and downwards. Left anterior descending (LAD) artery shows diffuse disease, while left circumflex (LCX) coronary artery shows severe stenosis in its distal segment and in the mid-segment of its major obtuse marginal branch. sinotubular junction. ${ }^{1}$ Its prevalence in general population is estimated to be $0.20 \% .^{1}$ Some consider it to be benign, while others have reported it to be associated with ischaemia, myocardial infarction, syncope and sudden

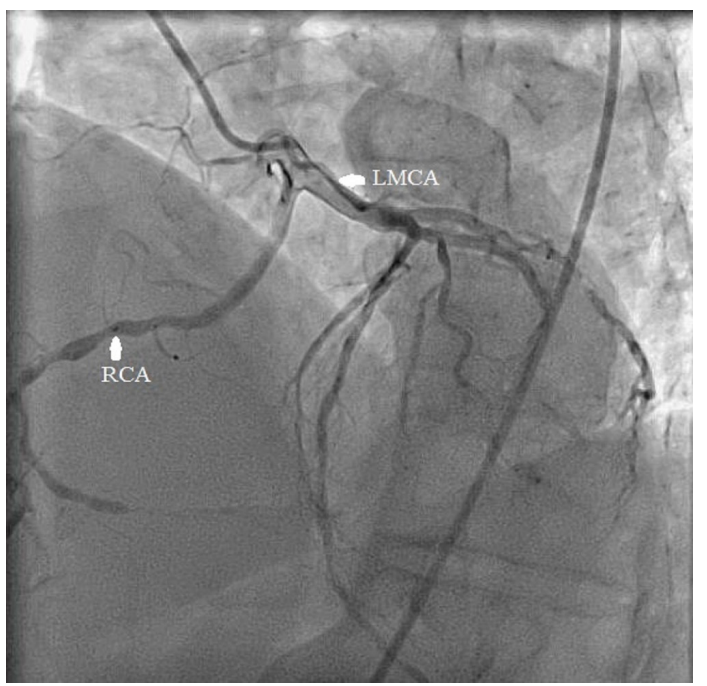

Figure 3 Coronary angiogram, left anterior oblique view, showing an anomalously originating right coronary artery (RCA) from the left main coronary artery (LMCA).

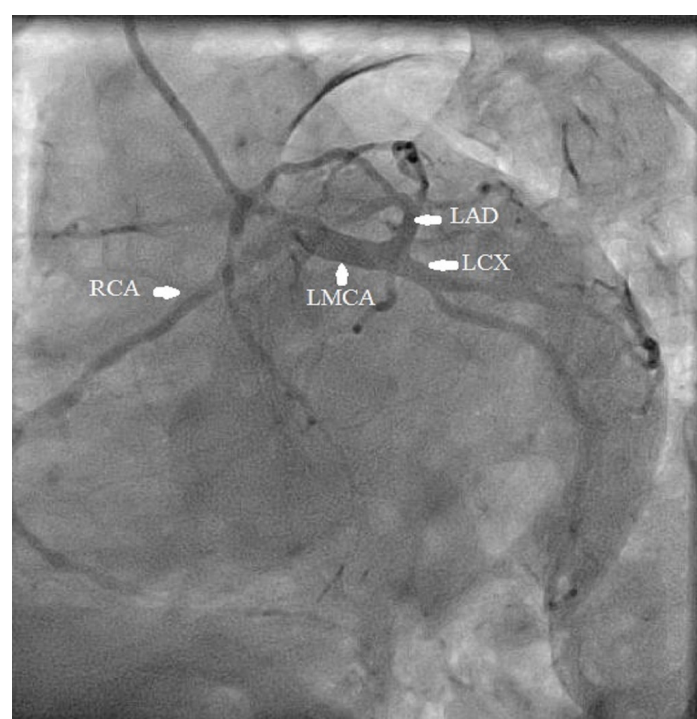

Figure 4 Coronary angiogram, left anterior oblique caudal view, showing an anomalously originating right coronary artery (RCA) from the left main coronary artery (LMCA). Left anterior descending (LAD) artery and left circumflex (LCX) coronary artery are seen following their normal course and branching. 
cardiac death. ${ }^{1}$ Similarly, single coronary artery is a rare coronary anomaly, where only one coronary artery originates from the single ostium from the aorta and supplies the entire heart. Its incidence varies between $0.0024 \%$ and $0.066 \%$ in those undergoing coronary angiography. ${ }^{2}$ It is extremely rare to find a single coronary artery with a high aortic take-off from the aorta, with only a few case reports available previously. ${ }^{3}$

A 65 -year-old man with diabetes presented with a history of chronic stable angina and a positive exercise stress test at low threshold. During his diagnostic coronary angiography, repeated attempts at cannulating either of the two coronary artery ostia were unsuccessful. Then, with the help of a right judkins catheter, we attempted a large non-specific injection to visualise the coronary arteries. During this, we accidently cannulated a single coronary artery with its ostium arising from the ascending aorta, $21 \mathrm{~mm}$ above the left coronary sinus (online supplementary video 1 and figure 1). Right coronary artery was dominant vessel and was visualised as anomalously originating from the left main coronary artery and turning downwards and medially to follow its familiar course and branching (figures 2-4). It was diffusely diseased starting from the mid-segment with severe stenosis in its distal part (online supplementary video 1 and figure 3). Left anterior descending artery was also diffusely diseased while left circumflex artery showed severe stenosis in its distal segment and in the mid-segment of major obtuse marginal branch (figures 2 and 3 ). In view of multivessel disease and abnormal anatomy, the patient was advised surgical intervention, but he refused. So, it was decided to follow the patient with optimal medical therapy and no progression of symptoms was recorded at 6-month follow-up.

Contributors AK and NG did the coronary angiography and made the diagnosis. KM wrote the manuscript. SS performed the literature search. All authors read and approved the final version of the manuscript.

Competing interests None declared.

Patient consent Obtained.

Provenance and peer review Not commissioned; externally peer reviewed.

(C) BMJ Publishing Group Ltd (unless otherwise stated in the text of the article) 2017. All rights reserved. No commercial use is permitted unless otherwise expressly granted.

\section{REFERENCES}

1 Loukas M, Andall RG, Khan AZ, et al. The clinical anatomy of high take-off coronary arteries. Clin Anat 2016;29:408-19.

2 Desmet W, Vanhaecke J, Vrolix M, et al. Isolated single coronary artery: a review of 50,000 consecutive coronary angiographies. Eur Heart J 1992;13:1637-40.

3 Lee JW, Lee KJ, Choi YJ. A single coronary artery originating above the left sinus of Valsalva. Eur J Cardiothorac Surg 2006;30:380.

Copyright 2017 BMJ Publishing Group. All rights reserved. For permission to reuse any of this content visit http://group.bmj.com/group/rights-licensing/permissions.

BMJ Case Report Fellows may re-use this article for personal use and teaching without any further permission.

Become a Fellow of BMJ Case Reports today and you can:

- Submit as many cases as you like

- Enjoy fast sympathetic peer review and rapid publication of accepted articles

- Access all the published articles

- Re-use any of the published material for personal use and teaching without further permission

For information on Institutional Fellowships contact consortiasales@bmjgroup.com

Visit casereports.bmj.com for more articles like this and to become a Fellow 